\title{
Thyroxine binding globulin excess detected by neonatal screening
}

\author{
Hye Young Jin, MD, PhD
}

Department of Pediatrics, Inje University Haeundae Paik Hospital, Inje University College of Medicine, Busan, Korea
Received: 14 April, 2016

Revised: 19 May, 2016

Accepted: 1 June, 2016

Address for correspondence:

Hye Young Jin, MD, PhD

Department of Pediatrics, Haeundae

Paik Hospital, Inje University College

of Medicine, 875 Haeun-daero,

Haeundae-gu, Busan 48108, Korea

Tel: +82-51-797-0609

Fax: +82-51-797-0298

E-mail: jinex79@naver.com
Inherited thyroxine binding globulin (TBG) disorder can be identified incidentally or through neonatal screening test. TBG excess is characterized by high levels of thyroxine (T4) but normal level of free T4 (fT4), while TBG deficiency presents with low T4 levels and normal fT4 levels. A 27-day-old newborn was brought to the hospital because of hyperthyroxinemia detected by neonatal screening. His T4 level was $18.83 \mu \mathrm{g} / \mathrm{dL}$ (normal range, $5.9-16.0 \mu \mathrm{g} / \mathrm{dL}$ ). His mother had no history of any thyroid disease. His fT4 and thyroid stimulating hormone (TSH) levels were 1.99 $\mathrm{ng} / \mathrm{dL}$ (normal range, 0.8-2.1 ng/dL) and $4.54 \mathrm{mlU} / \mathrm{L}$ (normal range, 0.5-6.5 mlU/ L), respectively. His serum total triiodothyronine (T3) level was $322.5 \mathrm{ng} / \mathrm{dL}$ (normal range, 105.0-245.0 ng/dL). His TBG level was $68.27 \mathrm{mg} / \mathrm{L}$ (normal range, 16.0-36.0 $\mathrm{mg} / \mathrm{L}$ ) at the age of 3 months. At 6 months and 12 months of age, his TBG levels were $48.77 \mathrm{mg} / \mathrm{L}$ (normal range, $16.0-36.0 \mathrm{mg} / \mathrm{L}$ ) and $50.20 \mathrm{mg} / \mathrm{L}$ (normal range, $14.0-28.0 \mathrm{mg} / \mathrm{L}$ ), respectively, which were 2 to 3 times higher than normal values. Hormonal studies showed consistently elevated T3 and T4 levels and upper normal levels of fT4 and free T3 with normal TSH levels. His growth and development were normal. TBG excess should be considered as a potential differential diagnosis for hyperthyroxinemia and especially high T3 levels with normal TSH concentration.

Keywords: Thyroxine-binding globulin, Hyperthyroxinemia, Triiodothyronine

\section{Introduction}

Thyroxine binding globulin (TBG), prealbumin or transthyretin, and albumin are all thyroid hormone $(\mathrm{TH})$ binding proteins ${ }^{1)}$. In the euthyroid state, approximately $0.03 \%$ and $0.3 \%$ of total thyroxine (T4) and triiodothyronine (T3) concentrations, respectively, are present in free or unbound forms ${ }^{2}$. TH serum transport proteins are responsible for maintaining of an extrathyroidal pool of TH, which prevents fluctuations of hormone levels. Another function of TH serum transport proteins is to provide macromolecular properties to small iodothyronine molecules, thereby, limiting urinary loss of iodine. TH serum transport proteins also enable the uniform cellular distribution of T4 and allow communication to all cells within the organ tissue $^{3)}$. Among the three TH binding proteins, TBG binds $75 \%$ of the serum T4 because of its high affinity, even though serum albumin is particularly abundant. The existence of inherited TBG abnormalities was first discovered in 1959, and the first TBG mutation was identified in $1989^{4,5)}$. Usually TBG deficiency or excess are found incidentally through tests that indicate abnormal serum T4 and normal free T4 (fT4) concentrations. The neonatal screening system also enables the identification of TBG deficiency or excess disorders. The prevalence of complete and partial deficiency of TBG is approximately 1:15,000 in newborn males and 1:4,000 in all newborns, respectively ${ }^{6}$. Inherited TBG excess is estimated to occur in approximately 1 in 15,000-25,000 individuals ${ }^{7,8)}$. At the follow-up appointments of 101 newborns that were referred because of elevated $\mathrm{T} 4$ concentration from a screening population of $80,884,10$ of the infants had indications of TBG excess, suggesting that TBG excess might 
be underdiagnosed in our field ${ }^{9}$. There has been no published report about TBG excess in Korea, while cases with TBG deficiency were reported previously ${ }^{10-13)}$. Inherited TBG excess is an important differential diagnosis for hyperthyroxinemia and high T3 level, although its clinical progression is benign. Here, we report a case of TBG excess in an infant who was referred because of a high T4 level that was detected through neonatal screening test.

\section{Case report}

A 27-day-old newborn was brought to the outpatient clinic because hyperthyroxinemia was detected through his neonatal screening test. He was born at the gestational age of $39^{+2}$ weeks with a birth weight of $3,240 \mathrm{~g}$ (25th-50th percentile). He was the first child in his family. The previous hospital noted that his serum T4 level was $18.83 \mu \mathrm{g} / \mathrm{dL}$ (normal range, 5.9-16.0 $\mu \mathrm{g} / \mathrm{dL}$ ) and his serum thyroid stimulating hormone (TSH) level was 1.59 $\mathrm{mIU} / \mathrm{L}$ (normal range, $0.5-6.5 \mathrm{mIU} / \mathrm{L}$ ). His mother did not have a history of thyroid disease. His fT4 level was $1.99 \mathrm{ng} / \mathrm{dL}$ (normal range, $0.8-2.1 \mathrm{ng} / \mathrm{dL}$ ) and his T3 level was $322.5 \mathrm{ng} / \mathrm{dL}$ (normal range, $105.0-245.0 \mathrm{ng} / \mathrm{dL}$ ). Thyroglobulin antibody, thyroid peroxidase antibody, and thyrotropin-binding inhibitory immunoglobulin were $3.0 \mathrm{IU} / \mathrm{mL}$ (normal range, $<1.0 \mathrm{IU} / \mathrm{mL}$ ), $0.4 \mathrm{IU} / \mathrm{mL}$ (normal range, $<20.0 \mathrm{IU} / \mathrm{mL}$ ), and $<0.3 \mathrm{IU} / \mathrm{L}$ (normal range, $<1.0 \mathrm{IU} / \mathrm{L})$, respectively.

Thyroid function test was repeated at 2 months of age. His serum T3 and fT4 levels were $320.0 \mathrm{ng} / \mathrm{dL}$ (normal range, $105.0-245.0 \mathrm{ng} / \mathrm{dL}$ ) and $2.03 \mathrm{ng} / \mathrm{dL}$ (normal range, $0.8-2.1 \mathrm{ng} /$ $\mathrm{dL}$ ), respectively. His TSH level was $3.53 \mathrm{mIU} / \mathrm{L}$ (normal range, 0.5-6.5 mIU/L). At 3 months of age, his serum T3 and free T3 (fT3) levels were $276.4 \mathrm{ng} / \mathrm{dL}$ (normal range, 105.0-245.0 ng/ $\mathrm{dL}$ ) and $5.03 \mathrm{ng} / \mathrm{dL}$ (normal range, $2.5-7.0 \mathrm{ng} / \mathrm{dL}$ ), respectively. His serum T4 and fT4 levels were $20.60 \mathrm{ng} / \mathrm{dL}$ (normal range, $5.9-16.0 \mathrm{ng} / \mathrm{dL}$ ) and $1.86 \mathrm{ng} / \mathrm{dL}$ (normal range, $0.8-2.1 \mathrm{ng} /$ $\mathrm{dL}$ ), respectively. His TBG level was $68.27 \mathrm{mg} / \mathrm{L}$ (normal range, $16.0-36.0 \mathrm{mg} / \mathrm{L}$ ). Mutational analysis of the MCT8 and TR $\beta$ genes to rule out peripheral TH resistance was negative. His height was $63 \mathrm{~cm}$ (25th-50th percentile) and weight was $6.4 \mathrm{~kg}$ (10th-25th percentile) at 3 months of age. At 6 months of age, his serum T3 and T4 levels were $322.1 \mathrm{ng} / \mathrm{dL}$ (normal range, $105.0-245.0 \mathrm{ng} / \mathrm{dL}$ ) and $16.70 \mathrm{ng} / \mathrm{dL}$ (normal range, 5.9-16.0 $\mathrm{ng} / \mathrm{dL}$ ), respectively. His TSH and fT4 levels were $2.68 \mathrm{mIU} / \mathrm{L}$ (normal range, $0.5-6.5 \mathrm{mIU} / \mathrm{L}$ ) and $1.71 \mathrm{ng} / \mathrm{dL}$ (normal range, $0.8-2.1 \mathrm{ng} / \mathrm{dL}$ ), respectively, and his TBG level was $48.77 \mathrm{mg} / \mathrm{L}$ (normal range, 16.0-36.0 mg/L). His height was $72 \mathrm{~cm}$ (75th90th percentile) and weight was $8.5 \mathrm{~kg}$ (50th-75th percentile) at 6 months of age. Examination of his development indicated that he could crawl and make polysyllabic vowel sounds.

When he turned 12 months of age, his height and weight reached $80.3 \mathrm{~cm}$ (75th-90th percentile) and $10.3 \mathrm{~kg}$ (25th-50th percentile), respectively. He could walk unaided and speak a few words. Laboratory findings were similar to the previous results. His serum T3 and T4 levels were $333.3 \mathrm{ng} / \mathrm{dL}$ (normal range, $105.0-269.0 \mathrm{ng} / \mathrm{dL}$ ) and $21.30 \mathrm{ng} / \mathrm{dL}$ (normal range, 7.3-15.0 $\mathrm{ng} / \mathrm{dL}$ ), respectively. His TSH, fT3 and fT4 levels were $2.69 \mathrm{mIU} /$ $\mathrm{L}$ (normal range, $0.6-8.0 \mathrm{mIU} / \mathrm{L}$ ), $6.48 \mathrm{ng} / \mathrm{dL}$ (normal range, $2.8-5.2 \mathrm{ng} / \mathrm{dL}$ ) and $1.82 \mathrm{ng} / \mathrm{dL}$ (normal range, $0.8-2.0 \mathrm{ng} / \mathrm{dL}$ ), respectively. His T3 uptake value was $19.1 \%(27 \%-37 \%)$, and his TBG level was $50.20 \mathrm{mg} / \mathrm{L}$ (normal range, $14.0-28.0 \mathrm{mg} / \mathrm{L}$ ). His mother showed normal thyroid function with the TBG level of $24.09 \mathrm{mg} / \mathrm{L}$ (normal range, 12.0-26.0 mg/L). During the followup period, his T4, and especially T3 levels were consistently elevated, while his fT3 and fT4 levels were within the high normal range (Table 1). He did not take any medication and maintained a clinically euthyroid state until his last follow-up at the age of 12 months.

\section{Discussion}

Hyperthyroxinemia can be detected through neonatal screening test ${ }^{9}{ }^{914}$. Sometimes, children and adolescents may be brought to the hospital because of high fT4 levels. Among the neonates and children referred because of hyperthyroxinemia, patients with suppressed levels of TSH and positive antithyroid autoantibodies are diagnosed with Graves disease. In the newborn period, neonatal Graves disease can be caused by the mother having Graves disease. When patients exhibit elevated hyperthyroxinemia with normal or increased TSH levels, the possible causes include loss of function mutations in the TH receptor that lead to TH resistance, and mutations in the $A L B$ gene that cause increased affinity for

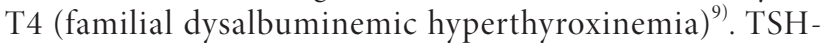
secreting adenoma is a rare, but potential disease that lead to hyperthyroxinemia and elevated levels of the free alpha-subunit of TSH.

Except for the diseases mentioned above, TBG excess should be considered as a possible cause for elevated T3 and T4 with unexpectedly normal TSH and increased TBG levels. TBG is a $54-\mathrm{kDa}$ glycoprotein composed of a single polypeptide chain

Table 1. Serial thyroid hormone levels during follow-up period

\begin{tabular}{lccccccc}
\hline Thyroid hormone & 1 Month & 2 Months & 3 Months & 4 Months & 6 Months & 1 Year & Normal range \\
\hline T3 $(\mathrm{ng} / \mathrm{dL})$ & 322.5 & 320.0 & 276.4 & 297.1 & 322.1 & 333.3 & $105.0-245.0$ \\
T4 $(\mu \mathrm{g} / \mathrm{dL})$ & 18.83 & - & 20.60 & 17.30 & 16.70 & 21.30 & $5.9-16.0$ \\
Free T3 $(\mathrm{pg} / \mathrm{mL})$ & - & - & 5.03 & 5.95 & - & 6.48 & $2.5-7.0$ \\
Free T4 $(\mathrm{ng} / \mathrm{dL})$ & 1.99 & 2.03 & 1.86 & 1.86 & 1.71 & 1.82 & $0.8-2.1$ \\
TSH $(\mathrm{mlU} / \mathrm{L})$ & 4.54 & 3.53 & 2.84 & 3.39 & 2.68 & 2.69 & $0.5-6.5$ \\
TBG $(\mathrm{mg} / \mathrm{L})$ & - & - & 68.27 & 53.92 & 48.77 & 50.20 \\
\hline
\end{tabular}

T3, triiodothyronine; T4, thyroxine; TSH, thyroid stimulating hormone; TBG, thyroxine binding globulin. 
and 4 carbohydrate residues ${ }^{3)}$. It is encoded by a single gene copy in the long arm of the $\mathrm{X}$ chromosome ${ }^{15}$. TBG carries T4 in a surface pocket via hydrophobic interaction. The coordinated in and out movement of the reactive center peptide loop of TBG facilitates equilibrated binding and release of $\mathrm{TH}^{6}$. While complete or partial TBG deficiency are generally caused by mutations in the TBG gene, TBG excess is known to be caused by gene duplication or triplication ${ }^{6,16-18)}$. Unequal crossing over during meiosis was suggested as a mechanism of this duplication or triplication mutation ${ }^{18)}$. The gene dosage was associated with the serum concentration of TBG, according to previous reports ${ }^{17,18)}$. Thus, affected males carry $2-3$ times higher TBG levels than normal individuals, and heterozygous females have TBG concentrations intermediate to those of affected and unaffected males ${ }^{17}$.

Circulating levels of TH and carrier proteins change with age. TBG concentrations are higher in children than in adults, and its level decreases during adolescence. The concentration of TBG can be affected by acute illness and exposure to estrogen, which explains the relatively high concentrations of TBG during neonatal period. Because these factors can affect the concentration of TBG, follow-up hormonal studies are needed to confirm inherited TBG excess when hyperthyroxinemia is observed in newborns. An elevated TBG concentration of 2 or 3 times normal levels along with consistently high $\mathrm{T} 4$ and $\mathrm{T} 3$ levels strongly suggests TBG excess. In the case we present here, the levels of TBG seemed to decrease during the first few months of life. However, the TBG value remained 2 times the normal level at the last examination. The levels of fT3 and $\mathrm{fT} 4$ were in the upper normal ranges, while $\mathrm{T} 3$ and $\mathrm{T} 4$ were increased, which are compatible findings with those of TBG excess in previous reports ${ }^{17,18)}$. Another finding that indicates TBG excess is low T3 uptake. T3 uptake can be an estimate of the number of unoccupied T4-binding sites in the serum and T3 uptake is decreased in conditions with high TBG levels, such as acute illness, pregnancy, sex hormone exposure, and TBG excess.

Generally, people with TBG abnormalities do not need medical treatment because TBG excess or deficiency maintain clinically euthyroid state and has no effect on growth, development or general health. Thus, accurate diagnosis leads to avoid erroneous treatment in cases of hyperthyroxinemia or high T3 level. Genetic counseling should be given to the family members of the affected cases if mother is heterozygous for $T B G$ gene mutation considering the $\mathrm{X}$-linked inheritance pattern of TBG abnormalities.

\section{Conflict of interest}

No potential conflict of interest relevant to this article was reported.

\section{References}

1. Schussler GC. The thyroxine-binding proteins. Thyroid 2000;10:141-9.

2. Refetoff S, Robin NI, Fang VS. Parameters of thyroid function in serum of 16 selected vertebrate species: a study of PBI, serum T4, free T4, and the pattern of T4 and T3 binding to serum proteins. Endocrinology 1970;86:793805 .

3. Refetoff S. Thyroid hormone serum transport proteins. In: De Groot LJ, Beck-Peccoz P, Chrousos G, Dungan K, Grossman A, Hershman JM, et al., editors. Endotext [Internet]. South Dartmouth (MA): MDText.com Inc., 2000.

4. Beierwaltes WH, Robbins J. Familial increase in the thyroxine-binding sites in serum alpha globulin. J Clin Invest 1959;38:1683-8.

5. Mori Y, Seino S, Takeda K, Flink IL, Murata Y, Bell GI, et al. A mutation causing reduced biological activity and stability of thyroxine-binding globulin probably as a result of abnormal glycosylation of the molecule. Mol Endocrinol 1989;3:575-9.

6. Pappa T, Ferrara AM, Refetoff S. Inherited defects of thyroxine-binding proteins. Best Pract Res Clin Endocrinol Metab 2015;29:735-47.

7. Refetoff S. Inherited thyroxine-binding globulin abnormalities in man. Endocr Rev 1989;10:275-93.

8. Bhatkar SV, Rajan MG, Velumani A, Samuel AM. Thyroid hormone binding protein abnormalities in patients referred for thyroid disorders. Indian J Med Res 2004;120:160-5.

9. Lafranchi SH, Snyder DB, Sesser DE, Skeels MR, Singh $\mathrm{N}$, Brent GA, et al. Follow-up of newborns with elevated screening T4 concentrations. J Pediatr 2003;143:296-301.

10. Lee JW, Jin JY, Lee J, Lee DH, Hong YH. A study of thyroid function in partial thyroxine-binding globulin deficiency. Soonchunhyang Med Sci 2015;21:65-9.

11. Hur SM, Kim SH, Kim MJ, Byun DW, Suh KI, Yoo MH, et al. A case of hypothyroxinemia with thyroxine-bindingglobulin deficiency. Soonchunhyang Med Sci 2011;17:1613.

12. Park SJ, Suh JS, Jung MH, Lee HJ, Suh BK, Lee WB, et al. A single nucleotide deletion resulting in frameshift in two Korean neonates with thyroxine-binding globulin deficiency. Korean J Pediatr 2005;48:1252-5.

13. Lee DC, Lee SH, Yu JH. A case of thyroxine binding globulin deficiency with hypothyroidism. J Korean Pediatr Soc 2002;45:796-9.

14. Tajima T, Jo W, Fujikura K, Fukushi M, Fujieda K. Elevated free thyroxine levels detected by a neonatal screening system. Pediatr Res 2009;66:312-6.

15. Trent JM, Flink IL, Morkin E, van Tuinen P, Ledbetter DH. Localization of the human thyroxine-binding globulin gene to the long arm of the X chromosome (Xq21-22). Am J Hum Genet 1987;41:428-35.

16. Refetoff S. Abnormal thyroid hormone transport. In: De 
Groot LJ, Beck-Peccoz P, Chrousos G, Dungan K, Grossman A, Hershman JM, et al., editors. Endotext [Internet]. South Dartmouth (MA): MDText.com Inc., 2000.

17. Mori Y, Miura Y, Takeuchi H, Igarashi Y, Sugiura J, Saito H, et al. Gene amplification as a cause of inherited thyroxinebinding globulin excess in two Japanese families. J Clin
Endocrinol Metab 1995;80:3758-62.

18. Mori Y, Jing P, Kayama M, Fujieda K, Hasegawa T, Nogimori $\mathrm{T}$, et al. Gene amplification as a common cause of inherited thyroxine-binding globulin excess: analysis of one familial and two sporadic cases. Endocr J 1999;46:613-9. 